\title{
Analisis dan Perencanaan Pengembangan Sistem Distribusi Air Terhadap Pertumbuhan Proyek Pembangunan Apartemen di Zona 2 PDAM Kota Surabaya
}

\author{
Nadia Nafisa dan Wahyono Hadi \\ Departemen Teknik Lingkungan, Fakultas Teknik Sipil, Lingkungan dan Kebumian, \\ Institut Teknologi Sepuluh Nopember (ITS) \\ e-mail:wahyono@enviro.its.ac.id
}

\begin{abstract}
Abstrak-Pada tahun 2017, di Zona 2 distribusi PDAM Kota Surabaya dengan air yang di-supply dari IPAM Ngagel I, Ngagel III dan Karang Pilang III telah mampu melayani 97\% kebutuhan air penduduk. Sesuai dengan RISPAM Tahun 20142035, per tahun 2018 sistem jaringan perpipaan yang ada diharapkan mampu melayani $100 \%$. Permasalahan yang dialami PDAM Kota Surabaya ada pada jumlah penduduk yang terus bertambah dari tahun ke tahun, dibarengi dengan bermunculannya proyek pembangunan apartemen baru. Terdata sebanyak $41,57 \%$ pembangunan apartemen berada di Zona 2 dengan pertumbuhan $15.63 \%$ setiap tahunnya. Dibutuhkan analisis untuk mengetahui kondisi sistem distribusi eksisting dan merencanakan pengembangan untuk dapat melayani kebutuhan air penduduk. Metode yang digunakan dalam perhitungan dan perencanaan sesuai dengan kriteria perencanaan, RTRW Kota Surabaya dan RISPAM Tahun 2014-2035 yang dikeluarkan oleh PDAM Kota Surabaya. Analisis dan permodelan dilakukan menggunakan aplikasi WaterCAD. Hasil analisis menunjukkan bahwa kurangnya aliran air yang sampai ke sambungan rumah pelanggan disebabkan oleh kurangnya tekanan pada sistem dan tingginya unit headloss pada pipa. Mengantisipasi hal tersebut, dilakukan program pengembangan untuk jangka waktu sepuluh tahun dan terbagi dalam dua tahap, Tahap I (2018-2022) dan Tahap II (2023-2027). Pengembangan diasumsikan akan didukung dengan supply air tambahan dari proyek SPAM Umbulan, pemanfaatan kapasitas idle IPAM Karang Pilang III, serta proyek pembangunan reservoir baru Karang Pilang IV pada tahun 2024. Perencanaan pengembangan meliputi penambahan pipa distribusi secara paralel pada ruas pipa dengan nilai headloss yang tinggi dan pemaksimalan booster pompa yang ada. Rencana anggaran biaya untuk pengembangan PDAM Kota Surabaya sebesar Rp. 18,337,431,999.
\end{abstract}

Kata Kunci-Distribusi air, PDAM Kota Surabaya, Pertumbuham apartemen, WaterCAD, Zona 2.

\section{PENDAHULUAN}

$\mathrm{Z}$ ONA 2 merupakan salah satu dari lima zona pelayanan distribusi PDAM Kota Surabaya dengan besar pelayanan 97\% dari supply air IPAM Ngagel I, Ngagel III dan Karangpilang III [1]. Zona ini berada di wilayah Surabaya Timur yang merupakan salah satu target pihak swasta dalam mengembangkan usaha properti, khususnya pembangunan apartemen dan pusat perbelanjaan. Apartemen terbangun di wilayah ini memiliki porsi terbesar, sebesar $46 \%$, dibandingkan dengan empat wilayah lainnya [2].

Banyak jumlah gedung apartemen yang sudah, sedang, atau direncanakan pembangunannya, menyumbang peningkatan jumlah penduduk yang besar dan cendrung tidak terprediksi bagi wilayah Surabaya Timur. Jumlah penduduk yang meningkat akan menyebabkan terus bertambahnya jumlah demand air bersih untuk kegiatan mereka sehari-hari. Sedangkan dalam Rencana Induk SPAM (RISPAM) PDAM Kota Surabaya, mulai tahun 2018 ditargetkan mampu memberikan pelayanan air bersih $100 \%$ untuk seluruh Kota Surabaya [1].

Namun, melihat maraknya pembangunan properti berjenis apartemen dengan kapasitas penghuni yang tinggi, dikhawatirkan sistem SPAM eksisting sudah tidak mampu melayani kebutuhan pada akhir tahun perencanaan, sesuai yang diprediksi dalam RISPAM tahun 2014-2035. Dibutuhkan pendataan pertumbuhan pembangunan apartemen di lapangan. Data ini dapat menjadi acuan dalam memprediksi kebutuhan air bersih total dan analisis dalam menilai kesiapan PDAM mengantisipasi peningkatan kebutuhan air dalam periode perencanaan 10 tahun kedepan. Hasil analisis dilanjutkan dengan perencanaan pengembangan sistem distribusi air bersih untuk memenuhi kebutuhan air masyarakat.

\section{METODE PERENCANAAN}

\section{A. Perijinan}

Proses perijinan dilakukan dengan pembuatan proposal dan surat pengantar dari Departemen Teknik Lingkungan ITS yang ditujukan kepada pihak terkait. Pihak yang dimaksudkan antara lain PDAM Kota Surabaya, Bakesbangpol Kota Surabaya, Bappeko Kota Surabaya, Dinas Perumahan Rakyat dan Kawasan Permukiman, Cipta Karya dan Tata Ruang (DPUCKTR) Kota Surabaya dan pihak swasta pengembang properti. Proses perijinan dilakukan sesuai regulasi yang ada, lalu dilakukan proses pengambilan data yang dibutuhkan dari seluruh intansi tersebut.

\section{B. Pengumpulan Data Primer}

a) Data Pertumbuhan Pembangunan Gedung-gedung Apartemen dari tiap pengembang properti, dilakukan dengan survey pada kawasan Zona 2 yang meliputi tren pembangunan gedung apartemen dalam 10 tahun kedepan, jumlah unit properti yang dibangun, kapasitas penghuni, tahun operasi dan data teknik lainnya yang dapat menunjang kalkulasi jumlah kebutuhan air total.

b) Topografi dan Sistem Distribusi Jaringan Eksisting PDAM, data berupa nilai elevasi dan koordinat titik diperoleh melalui alat bandu Global Positioning System 
(GPS) pada titik-titik percabangan tertentu dengan tujuan memudahkan input permodelan jaringan pada aplikasi WaterCAD sehingga didapatkan data sesuai kondisi lapangan sebenarnya.

\section{Pengumpulan Data Sekunder}

1) Peta Rencana Tata Ruang Wilayah (RTRW) Kota Surabaya, untuk menentukan daerah yang akan dikembangkan.

2) Data Izin Mendirikan Bangunan (IMB) Gedung Apartemen, untuk memprakirakan pertumbuhan pembangunan gedung apartemen wilayah perencanaan.

3) Rencana Induk SPAM (RISPAM) Kota Surabaya Tahun 2014-2035, sebagai acuan untuk melakukan perencanaan pengembangan.

4) Data Kebutuhan Air, untuk mendapatkan nilai pemakaian air masyarakat.

5) Data Teknis lainnya, meliputi presentase pelayana, skema distribusi, jenis dan konsisi pipa distribusi, tingkat kehilangan air, dsb.

6) Data Jumlah Penduduk dan Fasilitas Umum, untuk memproyeksikan jumlah penduduk dan fasilitas umum serta kebutuhan air nya, sesuai periode perencanaan.

7) Harga Satuan Pokok Kegiatan (HSPK) dan Data Harga Kelengkapan SPAM, untuk merencanakan rencana anggaran biaya pengembangan SPAM Kota Surabaya.

\section{Pengolahan Data}

1) Proyeksi Pembangunan Gedung Apartemen; dilakukan untuk melihat tren perkembangan/pertumbuhan proyek pembangunan apartemen kedepannya.

2) Proyeksi Penduduk Dan Fasilitas Umum; dilakukan untuk memperkirakan jumlah penduduk yang akan dilayani pada masa yang akan datang. Proyeksi dilakukan untuk jangka waktu 10 tahun ke depan lewat pemilihan salah metode; Aritmatik, Geometrik ataupun Least Square.

3) Kebutuhan Air Total; dihitung menggunakan debit jam puncak total dengan faktor jam puncak 1.2 debit ratarata. Kebutuhan air yang diperhitungkan adalah kebutuhan air domestik, non-domestik, pemadam kebakaran dan estimasi kebocoran. Kebutuhan air domestic didapatkan dari pengolahan data sekunder proyeksi penduduk subzona wilayah perencanaan, ditambah dengan kebutuhan air dari pengolahan data pertumbuhan pembangunan gedung apartemen di Zona 2 hasil survey kepada pihak swasta pengembang properti. Kebutuhan non-domestik dihitung 30\% dari kebutuhan domestik. Estimasi tingkat kebocoran air dapat dihitung berdasarkan jumlah air yang diproduksi oleh PDAM Kota Surabaya dan air yang terjual ke pelanggan. Kebutuhan air setiap orang dan fasilitas umum, dapat diperkirakan dengan data sekunder dari PDAM. Data yang dapat digunakan sebagai acuan adalah data dari RIPSPAM Kota Surabaya Tahun 2014-2035.

4) Sistem Distribusi dan Tingkat Pelayanan; keadaan eksisting di tingkat pelanggan dapat diketahui dari hasil running menggunakan software WaterCAD sistem distribusi yang ditinjau adalah jaringan pipa yang tidak memenuhi kriteria berdasarkan Pedoman / Petunjuk Teknis. Perencanaan wilayah pengembangan disesuaikan dengan ketersediaan air dibandingkan dengan tingkat kebutuhan pada tahun perencanaan. Wilayah pengembangan disesuaikan dengan RISPAM
PDAM Kota Surabaya tahun 2014-2035, RTRW Kota Surabaya

\section{E. Permodelan Kondisi Eksisting dengan Aplikasi WaterCAD}

Data-data yang telah lengkap, kemudian diaplikasikan menggunakan software WaterCAD untuk melakukan pengolahan data. Data-data yang dimasukkan ke dalam software WaterCAD adalah data primer dan data sekunder. Hasil running berupa kecepatan aliran, tekanan air dalam pipa, dan lain - lain. Hasil running WaterCAD akan digunakan untuk mengevaluasi kondisi eksisting jaringan pipa dengan cara membandingkan kondisi eksisting distribusi dengan sistem yang ideal (memenuhi kriteria desain). Evaluasi jaringan eksisting juga didukung dengan pengamatan langsung di lapangan.

Pengembangan sistem distribusi ini dilakukan berdasarkan beberapa pertimbangan yang meliputi kebijakan strategis daerah bidang SPAM, tata guna lahan, rencana tata ruang Kota Surabaya dan pengamatan kondisi lapangan yang ada. Perencanaan pengembangan ini diupayakan tidak mengubah kondisi eksisting yang telah ada. Hal tersebut dikarenakan pertimbangan teknis dan juga ekonomi dalam penggantian pipa eksisting. Pengembangan disesuaikan dengan RTRW dan RISPAM Kota Surabaya, per-5 tahunan, menjadi Tahap I: 2017-2022 dan Tahap II: 2023-2027. Software WaterCAD digunakan untuk membuat skema rencana pengembangan dikarenakan hasilnya yang akurat dan mudah diaplikasikan.

\section{HASIL DAN PEMBAHASAN}

\section{A. Analisis Kondisi Eksisting Sistem Distribusi}

1) Tingkat Pelayanan

Berdasarkan data yang dihimpun oleh BPS Kota Surabaya, pada tahun 2013 terdapat sebanyak 560.830 KK. Jumlah penduduk kota secara keseluruhan berjumlah 2.804.150 jiwa. Dengan membandingkan jumlah 5 orang/KK, dihitung sebagai berikut:

$\mathrm{n}$ Penduduk Terlayani $=$ Jumlah SR $\times$ Rasio $\mathrm{n}$ penduduk per $\mathrm{KK}=507.557 \mathrm{SR} \times 5$ jiwa/SR $=2.537 .785$ jiwa

$\%$ Pelayanan $=\frac{n \text { Penduduk terlayani }}{n \text { Wilayah terlayani }}=\frac{2.537 .785}{2.804 .150}=90.5 \%$

Berdasarkan perhitungan diatas diketahui tingkat pelayanan PDAM di Kota Surabaya pada tahun 2013 adalah sebesar 90,5 \%. Sesuai RISPAM tahun 2014-2035, direncanakan perhitungan cakupan pelayanan terus meningkat mengikuti target Pemerintah Kota yaitu 100\% mulai tahun 2018

Tabel 1 .

Debit Produksi yang Mengalir ke dalam Zona 2

\begin{tabular}{cccc}
\hline \hline No. & Sumber & Kapasitas & $\begin{array}{c}\text { Q Eksisting yang } \\
\text { Mengalir ke Zona 2 }\end{array}$ \\
\hline 1 & IPA Ngagel I & 1.800 & 1.800 \\
2 & IPA Ngagel II & 1.000 & - \\
3 & IPA Ngagel III & 1.750 & 1.750 \\
4 & IPA Karangpilang I & 1.450 & - \\
5 & IPA Karangpilang II & 2.500 & - \\
6 & IPA Karangpilang III & 2.000 & 1.007 \\
7 & Mata Air Umbulan & 1.000 & 500 \\
\hline \hline
\end{tabular}

2) Unit Pelayanan

Dalam studi ini, ruang lingkup unit pelayanan akan dibatasi pada sistem pelayanan distribusi Zona 2 dengan total 28 subzona. Data kebutuhan air selanjutnya akan didapatkan dengan memproyeksikan data SR pada tiap subzona sesuai data jumlah SR yang terdata oleh PDAM Kota Surabaya dari tahun 2011-2016. 


\section{3) Analisis Kebutuhan Air}

Kebutuhan air Kota Surabaya didasarkan atas kebutuhan domestik, non-domestik dan cadangan untuk pemadam kebakaran (PMK). Kebutuhan air domestik berupa penggunaan pada rumah tempat tinggal, sementara kebutuhan non-domestik didasarkan atas penggunaan air bagi kegiatan di luar kegiatan rumah tangga (perkantoran, fasilitas ibadah, fasilitas pendidikan, bangunan komersial, prasarana umum dan industri) yang jumlah nya $30 \%$ dari kebutuhan domestik. Sedangkan cadangan PMK disediakan 5\% dari kebutuhan air domestik. Nilai kebutuhan air adalah sebesar $1815.12 \mathrm{~L} / \mathrm{s}$.

\section{4) Kehilangan Air}

Pada tahun 2017, data menunjukkan bahwa jumlah air yang didistribusikan kepada pelanggan berjumlah $287,245,744 \mathrm{~m}^{3} /$ tahun dan jumlah air yang sampai ke pelanggan berjumlah $205,048,585 \mathrm{~m}^{3} /$ tahun. Jumlah air yang hilang adalah selisih dari keduanya. Berikut perhitungan kehilangan air dan presentase kehilangan airnya:

Kehilangan air $=\Sigma$ air produksi $-\Sigma$ air konsumsi

$$
\begin{aligned}
& =(287,245,744-205,048,585) \mathrm{m}^{3} \\
& =82,197,159 \mathrm{~m}^{3}
\end{aligned}
$$

$\%$ Kehilangan air $=\frac{\Sigma \text { air produksi }-\Sigma \text { air konsumsi }}{\Sigma \text { air produksi }} \times 100 \%$

$$
\begin{aligned}
& =\frac{82,197,159}{287,245,744} \times 100 \% \\
& =27 \%
\end{aligned}
$$

Nilai persen kehilangan air yang digunakan akan mengikuti proyeksi yang tertulis dalam RISPAM tahun 20142035 yang diasumsikan terus menurun tiap tahunnya. Diharapkan nilai kehilangan air mampu menyentuh angka 20.5\% pada akhir tahun perencanaan Tahap II, pada tahun 2027. Setelah ditambah dengan debit kebocoran, nilai kebutuhan air eksisting $2766.2 \mathrm{~L} / \mathrm{s}$.

Tabel 2.

Proyeksi Jumlah Tambahan Unit Dan Tower Apartemen

\begin{tabular}{cccc}
\hline \hline Tahun & Total Unit & $\begin{array}{c}\text { Tambahan } \\
\text { Unit }\end{array}$ & $\begin{array}{c}\text { Tambahan } \\
\text { Tower }\end{array}$ \\
\hline 2022 & 25.018 & 2.411 & 2 \\
2023 & 28.929 & 3.911 & 3 \\
2024 & 33.452 & 4.523 & 4 \\
2025 & 38.682 & 5.230 & 4 \\
2026 & 44.730 & 6.048 & 5 \\
2027 & 51.723 & 6.993 & 6 \\
\hline \multicolumn{2}{r}{ Total Tambahan Tower Apartemen } & 24 \\
\hline \hline
\end{tabular}

\section{5) Analisis Kapasitas Produksi}

Sumber air baku PDAM Kota Surabaya berasal 97\% dari air permukaan yaitu sungai Surabaya yang sebelumnya telah melalui IPAM, serta 3\% berasal mata air. Jumlah masingmasing kapasitas produksi yang ada hanya akan digunakan sesuai debit produksi yang mengalir dalam batas Zona 2 . Berikut nilai debit yang mengalir di dalam jaringan distribusi Zona 2.

Secara garis besar, kapasitas produksi yang ter-supply oleh jaringan perpipaan PDAM yang masuk ke dalam Zona 2 adalah sebesar 5500 L/detik. Nilai ini didapatkan dari kapasitas maksimal ketiga IPA yaitu Ngagel I, Ngagel III dan Karangpilang III.

\section{6) Analisis Sistem Distribusi Eksisting Menggunakan} WaterCAD

Hasil running program WaterCAD adalah keadaan air pada pipe (pipa) dan junction (percabangan). Pipe akan menggambarkan pipa pada jaringan. Pipa pada WaterCAD setelah running menunjukkan hasil berupa flow (arah aliran), velocity (kecapatan dalam pipa), serta headloss (tekanan yang hilang selama perjalanan). Aspek yang dianalisis menggunakan WaterCAD adalah kecepatan aliran, sisa tekan dan headloss dengan kriteria sebagai berikut:

- Kecepatan : $(0,3-3,0) \mathrm{m} / \mathrm{s}$

- Sisa Tekan : min. $10 \mathrm{~m} \mathrm{H}^{2} 0$

- Headloss max.: $10 \mathrm{~m} / \mathrm{km}$

Analisis terpenting pada junction adalah pressure (tekanan), dimana akan sangat mempengaruhi pipa dan jaringan apabila nilainya melebihi tekanan maksimal karena pipa sangat berpotensi bocor. Dan apabila tekanan berada di bawah ambang nilai minimum, aliran air dalam pipa akan menjadi sangat kecil. Bila kecepatan yang muncul kurang dari standar maka pipa berpotensi mengalami pengandapan, sedangakan bila kecepatan terlampau besar maka pipa berpotensi mengalami pengikisan akibar aliran air yang terlalu cepat. Terakhir, headloss menunjukkan besar friksi yang dihasilkan pada pipa karena adanya gesekan. Kondisi seluruh junction yang ada pada jaringan distribusi eksisting memiliki nilai kecepatan, sisa tekan dan headloss yang normal.

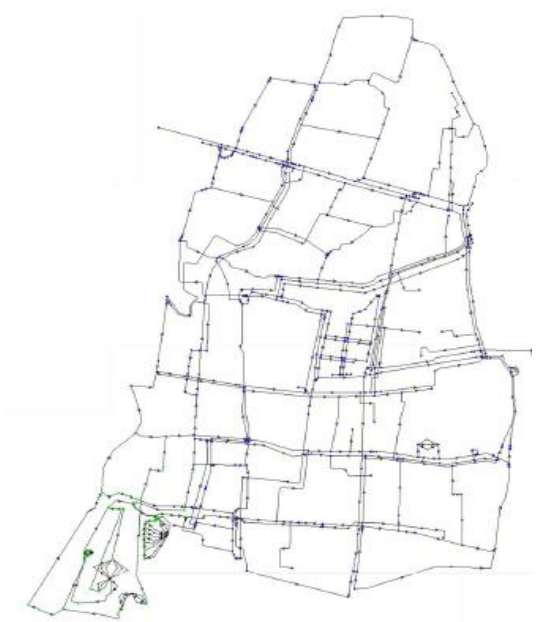

Gambar 1. Model Jaringan WaterCAD Eksisting.

\section{B. Rencana Pengembangan Jaringan Distribusi}

\section{1) Proyeksi Pembangunan Apartemen}

Proyeksi dilakukan menggunakan data jumlah unit terbangun (eksisting) tahun 2012-2017 dari data sekunder hasil pendataan lapangan yang dilakukan oleh PT. Colliers International Surabaya. Sedangkan jumlah unit pada 20182021 merupakan jumlah unit yang sudah memiliki izin dan sedang dalam tahap pembangunan yang didapatkan dari survey langsung kepada para pengembang, tercatat sebanyak 16 tower dari tiga belas proyek pembangunan berbeda. Perhitungan proyeksi jumlah unit akan dilakukan untuk tahun 2022-2027 menggunakan metode geometrik. Kemudian jumlah unit hasil proyeksi diplotkan pada tower dengan asumsi 1200 unit/tower. Lokasi tambahan tower tersebut ditempatkan sesuai RTRW Kota Surabaya yang berlaku. Perhitungan prakiraan jumlah tower yang akan dibangun hingga tahun 2027 ada pada Tabel 2 berikut.

Kebutuhan air untuk setiap tower akan dimasukkan ke dalam junction terdekat dari lokasi hasil plotting prakiraan persebaran pembangunan apartemen di Zona terhadap RTRW tersebut.

2) Proyeksi Penduduk

Perhitungan proyeksi penduduk akan menggunakan data time series jumlah SR eksiting untuk tiap subzone beberapa tahun sebelumnya, mulai tahun 2011-2017. Dimana setiap SR akan diasumsikan mampu melayani 5 orang/SR. 
Proyeksi penduduk dapat dihitung menggunakan salah satu metode, yaitu terpilih metode geometric setelah dilakukan pemilihan metode ditentukan dengan membandingkan hasil perhitungan nilai koefisien korelasi yang paling mendekati satu. Rumus metode geometrik:

$$
P n=P o+(1+r)^{d n}
$$

Keterangan:

$\mathrm{Pn}^{`}=$ jumlah penduduk tahun $\mathrm{n}$

Po = jumlah penduduk mula-mula

$\mathrm{r} \quad=$ rata-rata prosentase pertambahan penduduk per tahun

$\mathrm{dn}=$ kurun waktu proyeksi

3) Proyeksi Kebutuhan Air

Analisis kebutuhan air bersih untuk masa mendatang menggunakan standar-standar perhitungan yang telah ditetapkan. Kebutuhan air untuk fasilitas-fasilitas sosial ekonomi harus dibedakan sesuai peraturan PDAM dan memperhatikan kapasitas produksi sumber yang ada, tingkat kebocoran dan pelayanan. Faktor utama dalam analisis kebutuhan air adalah jumlah penduduk pada daerah studi [3].

Sesuai RISPAM, rumus perhitungan kebutuhan air ratarata pada perencanaan ini adalah:

$Q r=Q d+Q n+Q a+Q_{\text {PMK }}$

Keterangan:

Qr = kebutuhan air rata - rata $(\mathrm{L} / \mathrm{s})$

Qd = kebutuhan air domestik (L/s)

$=$ proyeksi pend.

$\mathrm{Qn}=$ kebutuhan air non domestik $(\mathrm{L} / \mathrm{s})=30 \% \mathrm{Qd}$

$\mathrm{Qa}=$ kehilangan air $(\mathrm{L} / \mathrm{s}) \quad=(27-20.5) \% \mathrm{Qd}$

$\mathrm{Q}_{\text {PMK }}=$ kebutuhan air pemadam kebakaran $=5 \%$ Qd

Namun, perhitungan dimensi pipa transmisi air baku biasanya berdasarkan pada debit maksimum harian (Qmaks, PDAM Surabaya menggunakan faktor 1.1), sedangkan pipa transmisi - distribusi air minum pada dasarnya dirancang untuk dapat mengalirkan debit aliran untuk kebutuhan Jam Puncak (Qpeak PDAM Surabaya menggunakan faktor 1.2) [1].

Kebutuhan air (water requirement) merupakan jumlah air yang diperlukan bagi kebutuhan dasar/unit konsumsi (water demand) dan kehilangan air serta (pertimbangan bagi) kebutuhan air pemadam kebakaran. Kebutuhan dasar berfluktuasi dari waktu ke waktu dengan skala jam, hari, minggu dan bulan dalam satu kurun waktu 1 tahun (untuk tinjauan 1 tahun). Hal ini mengarahkan perlunya tolak pengukuran penyediaan air bersih yang didasarkan pada kondisi maksimum.

\section{4) Kebutuhan Air Total Tiap Subzona}

Kebutuhan air yang diproyeksikan merupakan kebutuhan air domestik lewat proyeksi penduduk pada tiap subzona di Zona 2, sebesar 3590.9 L/s pada Tahap I dan $4389.2 \mathrm{~L} / \mathrm{s}$ pada Tahap II. Hasil proyeksi kebutuhan air subzona selanjutnya ditambahkan dengan proyeksi kebutuhan air apartemen yang nilainya $156.7 \mathrm{~L} / \mathrm{s}$ pada Tahap I dan $305.5 \mathrm{~L} / \mathrm{s}$ pada Tahap II.

Hasil proyeksi kebutuhan air total (penduduk subzone dan apartemen) jam puncak $\left(\mathrm{Q}_{\text {peak }}\right)$ pada 28 subzona tersebut dijadikan patokan dalam analisis dan perencanaan pengembangan pada Tahap I dan Tahap II. Kebutuhan air total pada Tahap I sebesar $3747.7 \mathrm{~L} / \mathrm{s}$ dan Tahap II sebesar $4851.5 \mathrm{~L} / \mathrm{s}$. Kebutuhan air total diplotkan pada tiap junction yang ada sesuai kondisi eksisting.

\section{5) Analisis Pengembangan Jaringan Menggunakan} WaterCAD

Analisis WaterCAD untuk pengembangan sistem distribusi dilakukan untuk Tahap I dan Tahap II. Data teknis untuk jaringan sama dengan kondisi eksisting. Perbedaan data yang dimasukkan dalam WaterCAD adalah pada kebutuhan air untuk junction subzona pelayanan. Data kebutuhan air disesuaikan dengan proyeksi kebutuhan air pada tahun 2022 untuk Tahap I dan tahun 2027 untuk Tahap II.

\section{- Analisis Pengembangan Tahap I}

Pada pengembangan Tahap I dilakukan penambahan cakupan pelayanan dengan penambahan sambungan dan kebutuhan air yang dilayani. Pada tahap ini, diasumsikan akan menerima supply air tambahan dari proyek SPAM Umbulan sebesar $500 \mathrm{~L} / \mathrm{s}$ dan kapasistas idle IPAM Karang Pilang III sebesar $500 \mathrm{~L} / \mathrm{s}$ untuk memenuhi demand. Kedua supply air tambahan akan masuk sebagai demand negatif di junction J-193.

Hasil modifikasi jaringan untuk memenuhi standar headloss, sisa tekan dan kecepatan dilakukan penambahan 12 ruas pipa paralel. Hal ini dilakukan karna merupakan tindakan paling ekonomis dan mudah dilakukan dibandingkan dengan mengganti (memperbesar) diameter pipa yang sudah ada. Pipa paralel diberi nama P-Paralel1, $\mathrm{P}$ Paralel2, P-Paralel3, P-Paralel4, P-Paralel5, P-Paralel6, PParale17, P-Parale18, P-Parale19, P-Parale110, P-Paralel11 dan P-Paralel12. Tindakan lain diberlakukan pada pompa booster ITS. Dari sebelumnya hanya dua pompa yang menyala, maka pada pada tahap ini dinyalakan ketiga nya untuk dapat mengakomodir kebutuhan debit yang mengalir.

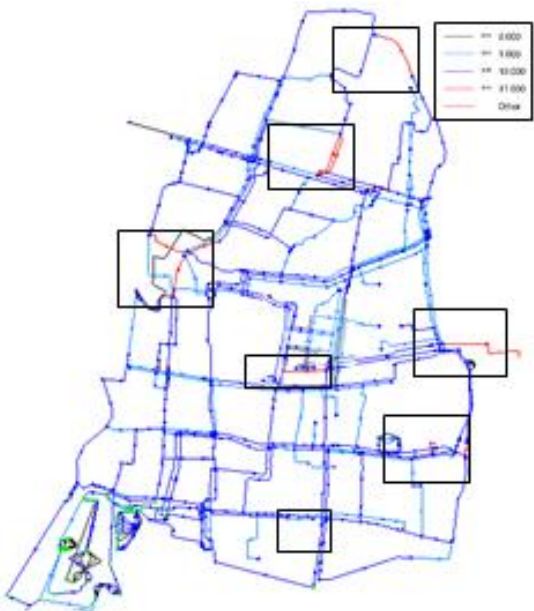

Gambar 2. Analisis Jaringan Perpipaan Sebelum Pengembangan Tahap I.

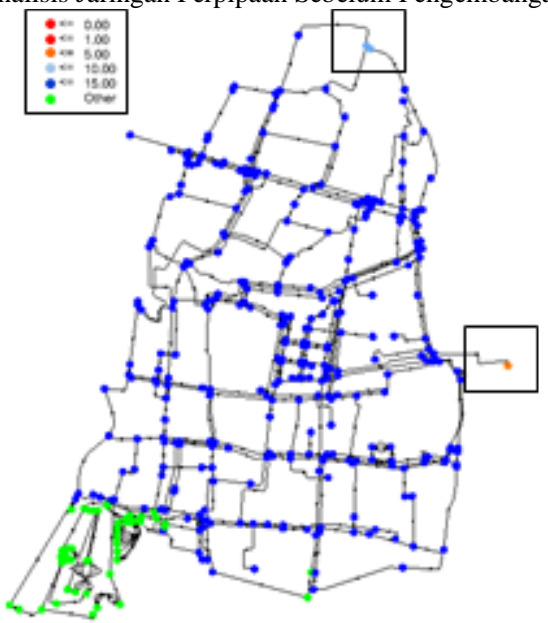

Gambar 3. Analisis Pressure Sebelum Pengembangan Tahap I.

- Analisis Pengembangan Tahap II

Pada pengembangan Tahap II terus dilakukan penambahan cakupan pelayanan dengan penambahan sambungan dan kebutuhan air yang dilayani. Berdasarkan RISPAM, PDAM Kota Surabaya merencanakan untuk menambah 
pasokan/supply air bersih lewat pembangunan reservoir baru Karang Pilang IV pada tahun 2024 dengan debit 1000 L/s. Seiring dengan terus bertambahnya kebutuhan air baik dari kebutuhan penduduk maupun kebutuhan proyek apartemen baru pada tahap ini, sistem distribusi Zona 2 diasumsikan akan menerima supply air tambahan lanjutan IPAM Karang Pilang IV sebesar $1000 \mathrm{~L} / \mathrm{s}$ untuk memenuhi demand. Supply air tambahan akan masuk sebagai demand negatif di junction J-193 sebesar 500L/s dan di J-436 sebesar 500L/s.

Hasil modifikasi jaringan untuk memenuhi standar headloss, sisa tekan dan kecepatan dilakukan penambahan 9 ruas pipa parallel dengan nama P-Paralel13, P-Paralel14, PParalel15, P-Paralel16, P-Paralel17, P-Paralel18, PParale119, P-Paralel20, P-Paralel21. Beberapa pipa parallel yang ditambahkan pada Tahap I mengalami nilai headloss yang kembali melewati batas. Maka dilakukan perhitungan diameter pipa baru untuk P-Paralel1B, P-Paralel5B, PParalel6B, P-Paralel10B dan P-Paralel11B.

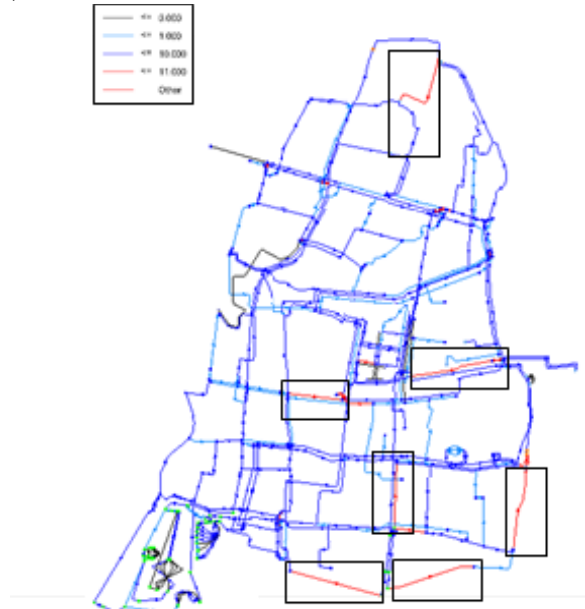

Gambar 4. Analisis Jaringan Perpipaan Sebelum Pengembangan Tahap II.

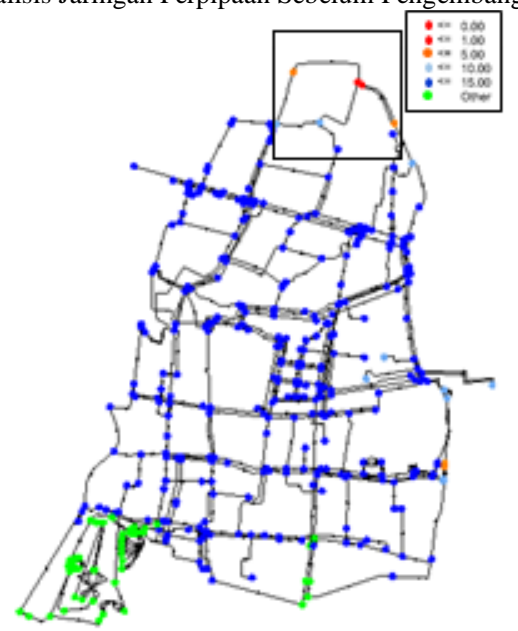

Gambar 5. Analisis Pressure Sebelum Pengembangan Tahap II

6) Analisis Kapasitas Debit Dan Kebutuhan Unit

Hasil analisis junction menggunakan WaterCAD dilakukan evaluasi pada reservoir dan kapasitas sumber yang tersedia. Hal tersebut diperlukan untuk mengecek apakah simulasi model sistem distribusi menggunakan WaterCAD dapat berjalan sesuai pada lapangan.

Berdasarkan RISPAM, PDAM Kota Surabaya merencakan untuk menambah pasokan/supply air bersih lewat pemanfaatan kapasitas idle Karang Pilang III dan lewat proyek SPAM Umbulan $500 \mathrm{~L} / \mathrm{s}$. Serta pembangunan reservoir baru Karang Pilang IV pada tahun 2024 dengan debit $1000 \mathrm{~L} / \mathrm{s}$. Hasil perbandingan pada Tabel 3 di atas, dapat diketahui bahwa seluruh debit kebutuhan reservoir pada unit pelayanan dapat terpenuhi oleh debit unit produksi sehingga hasil analisis dan simulasi WaterCAD dapat berjalan pada lapangan.

\section{Detail Junction}

Dilakukan perencanaan detail junction pada junction yang dimodifikasi untuk masing-masing tahap. Terdapat total tiga belas detail junction. Detail junction digambarkan setelah dilakukan perhitungan diameter pipa tapping pada masingmasing junction untuk blok pelayanan. Debit yang digunakan untuk perhitungan adalah proyeksi debit pada Tahap II karena mengantisipasi kebutuhan kedepannya. Perhitungan diameter pipa tapping menggunakan persamaan sebagai berikut:

$$
\begin{aligned}
& A=\frac{\text { Qtapping }}{V \text { asumsi }} \\
& D=\sqrt{\frac{4 x A}{\pi}} \\
& V \text { cek }=\frac{\text { Qtapping }}{\text { Atapping }}
\end{aligned}
$$

\section{Bill Of Quantity (BOQ) dan Rencana Anggaran Biaya (RAB) Pengembangan Sistem Distribusi}

BOQ dan RAB perpipaan merupakan analisis keperluan dan harga pipa, asesoris serta pekerjaan perpipaan. Analisis yang diperlukan untuk menghitung RAB perpipaan berupa perhitungan kebutuhan pipa, asesoris dan perhitungan harga pekerjaan perpipaan. Seluruh perhitungan RAB dari masingmasing detail kebutuhan rencana dijumlahkan, didapatkan rekapitulasi anggaran biaya yang dibutuhkan untuk pengembangan Tahap I dan Tahap II secara keseluruhan. Rekapitulasi perhitungan RAB dapat dilihat pada Tabel 4 berikut.

Tabel 3.

Perbandingan Kapasitas Sumber Dan Debit Kebutuhan Reservoir

\begin{tabular}{cccc}
\hline \hline Sumber & $\begin{array}{c}\text { Q } \\
\text { Supply } \\
(\mathbf{L} / \mathbf{s})\end{array}$ & Reservoir & $\begin{array}{c}\text { Q Demand } \\
(\mathbf{L} / \mathbf{s})\end{array}$ \\
\hline & 1.800 & R. Ngagel I & -689.1 \\
& 1.750 & R. Ngagel III & -1224.6 \\
Kali & & & $(-720.5)$ \\
Surabaya & 2.000 & R. Karangpilang III & $(-286.5)$ \\
& & & $(-500)$ \\
& \multirow{2}{*}{1.000} & R. Karangpilang IV & -1.507 \\
Mata Air & & Umbulan & -500 \\
\hline
\end{tabular}

Tabel 4.

Rekapitulasi Rencana Anggaran Biaya

\begin{tabular}{clc}
\hline \hline \multirow{2}{*}{ No. } & \multicolumn{1}{c}{ Rincian Kegiatan } & RAB \\
\hline 1 & Material Perpipaan & Rp.6.522.183.300 \\
2 & Pekerjaan Perpipaan & Rp. \\
3 & Pengadaan Asesoris & 11.711 .557 .549 \\
& Total RAB & Rp. 103.691.150 \\
& Rp.18.337.431.999 \\
\hline \hline
\end{tabular}

Jadi, kebutuhan total anggaran biaya perencanaan pengembangan PDAM Kota Surabaya dari pengadaan material perpipaan, pekerjaan perpipaan dan pengadaan asesoris adalah sebesar Rp. 18,337,431,999.

\section{KESIMPULAN}

1. Presentase pertumbuhan pembangunan proyek apartemen rata-rata, berdasarkan data yang telah terhimpun, adalah $15.63 \%$ setiap tahunnya.

2. Pada Tahap I diperkirakan terdapat tambahan 18 tower apartemen baru yang menyumbang tambahan kebutuhan air sebesar $156.79 \mathrm{~L} /$ detik dengan kebutuhan air total 
pada Zona 2 sebesar 3747.7 L/detik, dan pada Tahap II diprakirakan terdapat tambahan 22 tower apartemen baru yang menyumbang tambahan kebutuhan air sebesar 305.56 L/detik dengan kebutuhan air total pada Zona 2 sebesar 4694.7 L/detik.

3. Pengembangan jaringan distribusi hingga akhir periode perencanaan diasumsikan mendapat supply tambahan dari SPAM Umbulan dan kapasitas idle IPAM Karang Pilang III, serta Karang Pilang IV. Pola pengembangan adalah dengan terus mempertahankan pelayanan $100 \%$ kepada pelanggan, mempertahankan tekanan pada junction, serta memantau nilai headloss dan kecepatan pada pipa. Dilakukan penambahan pipa secara paralel pada ruas pipa eksisting dengan total 21 ruas pipa. Pompa booster dioperasikan secara maksimal untuk membantu mensuplai air ke subzone sesuai kebutuhan. Total RAB untuk penambahan pipa paralel pengembangan PDAM Kota Surabaya hingga akhir tahun 2027 adalah sebesar Rp. 18,337,431,999.

\section{UCAPAN TERIMA KASIH}

Ucapan terima kasih disampaikan kepada segenap pihak dari PDAM Surya Sembada Kota Surabaya atas bantuan dan dukungannya dalam menyelesaikan perencanaan ini.

\section{DAFTAR PUSTAKA}

[1] CV. Trimukti Andayani, "Revisi rencana induk SPAM (RISPAM) kota surabaya tahun 2014-2035," Surabaya, 2014.

[2] PT. Colliers International, "Colliers half year report: surabaya property market report (H2 2017)," Surabaya, 2017.

[3] H. Kalensun et al., "Perencanaan Sistem Jaringan Distribusi Air Bersih Di," J. Sipil Statik, vol. 4, no. 2, pp. 105-115, 2016. 